\title{
Hematology and serum biochemistry of captive gharial (Gavialis gangeticus) in India
}

\author{
Shahnaz Amin and Avadh Bihari Shrivastav \\ Centre for Wildlife Forensics and Health, Nanaji Deshmukh Veterinary Science University, \\ South Civil Lines, Jabalpur, Madhya Pradesh, India. \\ Corresponding author: Shahnaz Amin, e-mail: vetsamin@live.com, ABS: drabshrivastav@gmail.com \\ Received: 31-05-2014, Revised: 02-09-2014, Accepted: 07-09-2014, Published online: 09-10-2014 \\ doi: 10.14202/vetworld.2014.794-798. How to cite this article: Amin S, Shrivastav AB (2014) Hematology and serum \\ biochemistry of captive gharial (Gavialis gangeticus) in India, Veterinary World 7(10): 794-798.
}

\begin{abstract}
Aim: To study the hematological and serum biochemical parameters of the critically endangered gharial (Gavialis gangeticus).

Materials and Methods: Blood samples for hemato-biochemical analyses were collected from the ventral median coccygeal vein of six juvenile and six sub adult gharials of Dewari Gharial Rearing Centre of National Chambal Sanctuary, Madhya Pradesh, India. Hematological examination was performed manually. Differential leukocyte count was performed on the blood smears stained with Giemsa's stain. The analysis of serum was conducted by eppendorf ECOM-F 6124 semi auto biochemical analyzer using standard ERBA biochemical reagent kits.
\end{abstract}

Results: Peripheral blood cells of gharial showed erythrocytes with an oval outline and centrally located prominent round to oval nucleus. Erythrocyte count in sub adult gharials was significantly greater than juveniles. Whereas erythrocyte mean corpuscular volume and erythrocyte size in juveniles was significantly larger than sub adults. The average most abundant leukocyte type in gharial was lymphocytes (53\%), followed by heterophils (27\%), eosinophils (10\%), monocytes (7\%) and basophils (3\%). Aspartate aminotransferase, alkaline phosphatase, blood urea nitrogen, triglycerides and albumin concentrations in sub adult gharials were significantly higher than juveniles. No significant differences were determined in other hemato-biochemical parameters between juvenile and sub adult gharials under study.

Conclusion: A preliminary database on hematology and blood biochemistry of gharial was established. The data will be useful in routine health evaluations, especially in relation to determining potential effects associated with factors such as pollution and infectious diseases.

Keywords: crocodilians, gharial, Gavialis gangeticus, hematobiochemistry, National Chambal Sanctuary.

\section{I ntroduction}

The gharial is a unique crocodilian species, characterized by long thin jaws and a bulbous growth at the end of the snout in mature males. Gharial, being one of the largest living crocodilians, is now fighting for its existence and sadly enough this species is heading towards extinction. The convention on International Trade of Endangered Species of Wild Fauna and Flora, lists gharial in appendix I and the International union of the conservation of nature includes gharial on the red list as critically endangered species $[1,2]$.

Gharial is one of three crocodilians native to India, the other two being the mugger crocodile and the saltwater crocodile. In 2007-2008, gharial received attention with the demise of 111 individuals within a $35 \mathrm{~km}$ stretch of the Chambal river of National Chambal Sanctuary in Madhya Pradesh and Uttar Pradesh. The data on various health parameters of gharial is limited. Blood analysis is a minimally invasive method that can provide important clinical information about health and physiologic condition of animals [3].

Copyright: The authors. This article is an open access article licensed under the terms of the Creative Commons Attributin License (http:// creative commons.org/licenses/by/2.0) which permits unrestricted use, distribution and reproduction in any medium, provided the work is properly cited.
Since hematological and biochemical studies in gharial have not been published thus far, the present study was conducted to form a database on hematology and serum biochemistry of gharial.

\section{Materials and Methods}

\section{Ethical approval}

Methodology of the study was approved by the Ethical Research Committee of College of Veterinary Science and Animal Husbandry, Jabalpur, Madhya Pradesh, India.

\section{Location of work}

The work was carried out in the Centre for Wildlife Forensics and Health, Nanaji Deshmukh Veterinary Science University, Jabalpur and in the National Chambal Sanctuary. Rehabilitation of gharial has been taken up in the National Chambal Sanctuary from 1978. Over 3500 captive reared gharials have been reintroduced in the Chambal River by Madhya Pradesh and Uttar Pradesh State Forest Departments [2].

\section{Selection of animals}

The study was conducted on the juvenile and sub adult captive gharials raised at Dewari Gharial Rearing Centre of National Chambal Sanctuary. The samples for the hemato-biochemical studies were 
collected from six juvenile (age 1-5 years, total length 90.00-150.00 cm) and six sub adult (age 5-10 years, total length $150.00-270.00 \mathrm{~cm}$ ) gharials. Each animal was examined for signs of trauma, weight loss and abnormalities. A total 12 samples from apparently healthy gharials were studied.

\section{Blood collection}

Gharials were restrained physically, and care was taken to minimize stress on handling. Approximately 2.00-3.00 ml of blood was drawn aseptically, from the ventral median coccygeal vein of gharials using a sterile syringe and a 20 gauge needle. Each blood sample was divided into a vacutainer without anticoagulant, for biochemical analysis and a heparinized vacutainer (containing sodium heparin) for hematological studies. Direct blood smears were prepared for differential leukocyte count (DLC). Following the extraction of serum, the samples were refrigerated and transported immediately within a thermostatic container for analysis.

\section{Hematological studies}

The following hematological parameters were examined: Total erythrocyte count (TEC), hemoglobin $(\mathrm{Hb})$ estimation, packed cell volume (PCV), erythrocyte indices (Mean corpuscular volume [MCV], mean corpuscular hemoglobin $[\mathrm{MCH}]$ and mean corpuscular hemoglobin concentration [MCHC), total leukocyte count (TLC) and DLC.

The diluting fluid for blood cell counting was prepared as recommended by Natt and Herrick with slight modification [4]. The red blood cells were counted according to the procedure given by Feldman et al. [5]. Hb estimation was performed by the acid hematin method using Sahli's hemoglobinometer and expressed in g/dl of blood. PCV\% was determined by the micro hematocrit method, using a micro hematocrit centrifuge (RM-12 C DX micro centrifuge REMI model). The centrifuge was spun for 5 min at $12,000 \mathrm{rpm}$. The percentage PCV was determined by using a PCV reader. Erythrocyte indices were calculated as per the formulae given by Feldman et al. [5]. The counting of leukocytes was carried out as per the method described by the Natt and Herrick [4]. The blood smears were prepared on grease free clean micro slides. Each direct smear was stained with Giemsa's staining solution and a 100 cell DLC was performed under oil immersion objective [6].

The erythrocytes on Giemsa's stained blood smears were measured under a light microscope (Model Magnus-MEDILUX-12) according to the method followed by Arykan et al. [7], using a MOB-1$15 \times$ micrometrical ocular at $\times 300$ magnification. From each blood smear, 10 erythrocytes were chosen at random for the measurements of their lengths and widths. The sizes of the erythrocytes were calculated from:

Erythrocyte Size $(\mu \mathrm{m})=($ Erythrocyte length $[\mu \mathrm{m}] \times$ Erythrocyte width $[\mu \mathrm{m}] \times \pi) / 4$.

\section{Biochemical studies}

The analysis of serum was conducted within $24 \mathrm{~h}$ of extraction at room temperature by using eppendorf ECOM-F 6124 semi-automatic biochemical analyzer (Mannheim Bio-medicals Limited). ERBA biochemical reagent kits manufactured by Transasia Bio-medicals Ltd., daman for alanine aminotransferase, aspartate aminotransferase (AST), alkaline phosphatase (ALP), lactate dehydrogenase, total protein, albumin, creatinine, blood urea nitrogen (BUN), cholesterol and triglycerides were procured and used after development of metrics for each estimate. The methodology and the set reagents used in respect to each parameter were as per the recommendations of the manufacturer of analyzer system.

Hematological and serum biochemical data obtained was analyzed for statistically significant difference $(p<0.05)$ between all the values of two age classes by a two-sample t-test assuming unequal variances. In addition, significant differences $(\mathrm{p}<0.05)$ between means of erythrocyte size values of two age classes were also tested by a two-sample t-test assuming unequal variances. The mean and standard error of the values were calculated as per the standard procedure [8].

\section{Results}

The mean and range of hematologic and serum biochemical values of juvenile and sub adult gharials are given in Tables-1 and 2, respectively. Blood hemolysis or serum lipemia was not observed. The mean erythrocyte size was $782.38 \pm 13.92 \mu \mathrm{m}$ in juvenile and $654.21 \pm 7.10 \mu \mathrm{m}$ in sub adult gharials.

\section{Discussion}

The numbers of erythrocytes in reptiles are lower than birds and mammals. Among reptiles, lizards have the more numbers of erythrocytes than turtles and crocodiles. Consequently, there is a negative correlation between the number of erythrocytes and the body sizes [9]. The numbers of erythrocytes of gharial was in agreement with the stated correlation. However, the negative correlation did not exist intraspecifically in gharials. Since erythrocyte count in juveniles was significantly lower than the sub adult gharials. Similar observations were recorded in the Mugger crocodiles and Nile crocodiles [10,11]. Whereas, the measured erythrocytes sizes and MCV values in juvenile gharials were significantly greater than the sub adults. The erythrocytes in both juvenile and sub adult gharials measured smaller than amphibian erythrocytes and larger than erythrocytes of lizards, birds and mammals [12]. PCV is taken as the key parameter in the hematology of reptiles, because it provides tentative values of TEC and $\mathrm{Hb}$ concentration and can be developed as a sole parameter for health evaluation of smaller sized, younger, weak and sick reptiles, where collection of sufficient amount of blood required for complete hemogram 
Table-1: Hematological values of juvenile and sub adult gharials (G. gangeticus).

\begin{tabular}{|c|c|c|c|c|c|c|}
\hline \multirow[t]{2}{*}{ Parameters } & \multicolumn{3}{|c|}{ J uvenile gharials $(n=6)$} & \multicolumn{3}{|c|}{ Sub adult gharials $(n=6)$} \\
\hline & Mean & SE & Range & Mean & SE & Range \\
\hline TEC (millions/ $\mu \mathrm{l})$ & 0.91 & 0.06 & $0.75-1.13$ & 1.17 & 0.03 & $1.09-1.28$ \\
\hline $\mathrm{Hb}(\mathrm{g} / \mathrm{dl})$ & 7.01 & 0.87 & $4.00-9.10$ & 7.86 & 0.67 & $4.70-10.10$ \\
\hline PCV $(\%)$ & 19.36 & 0.84 & $17.30-23.00$ & 18.98 & 0.49 & $17.40-21.00$ \\
\hline $\operatorname{MCV}(f l)$ & 214.72 & 6.90 & $197.74-243.58$ & 161.57 & 4.15 & $148.59-179.37$ \\
\hline $\mathrm{MCH}(\mathrm{pg})$ & 77.24 & 9.25 & 46.51-108.97 & 66.62 & 5.21 & $42.92-81.12$ \\
\hline $\mathrm{MCHC}(\mathrm{g} / \mathrm{dl})$ & 36.11 & 4.31 & $21.85-52.00$ & 41.61 & 3.88 & $26.11-54.59$ \\
\hline TLC (thousands/ $\mu \mathrm{l}$ ) & 10 & 1.31 & $5.50-14.00$ & 10.70 & 0.37 & $9.00-12.00$ \\
\hline Heterophils (\%) & 26 & 1.76 & $21-33$ & 28.5 & 0.39 & $27-30$ \\
\hline Lymphocytes (\%) & 53.33 & 1.50 & $47-57$ & 51.83 & 0.72 & $49-54$ \\
\hline Eosinophils (\%) & 11 & 1.08 & $09-16$ & 9 & 0.41 & $07-10$ \\
\hline Monocytes (\%) & 3.83 & 0.44 & $02-05$ & 3.33 & 0.30 & $02-04$ \\
\hline Monocytes (\%) (with azurophillic granules) & 3 & 0.71 & $0-5$ & 4 & 0.24 & $3-5$ \\
\hline Basophils (\%) & 2.83 & 0.44 & $1-4$ & 3.33 & 0.19 & $3-4$ \\
\hline
\end{tabular}

SE: Standard error, TEC: Total erythrocyte count, Hb: Hemoglobin, PCV: Packed cell volume, MCV: Mean corpuscular volume, $\mathrm{MCH}$ : Mean corpuscular hemoglobin, MCHC: Mean corpuscular hemoglobin concentration, TLC: Total leukocyte count, G. gangeticus: Gavialis gangeticus

Table-2: Serum biochemical values of juvenile and sub adult gharials (G. gangeticus).

\begin{tabular}{|c|c|c|c|c|c|c|}
\hline \multirow[t]{2}{*}{ Parameters } & \multicolumn{3}{|c|}{ J uvenile gharials $(n=6)$} & \multicolumn{3}{|c|}{ Sub adult gharials $(n=6)$} \\
\hline & Mean & SE & Range & Mean & SE & Range \\
\hline$\overline{A L T}(I U / L)$ & 87.50 & 11.68 & $64.00-150.00$ & 114.00 & 6.04 & $98.00-142.00$ \\
\hline AST (IU/L) & 39.66 & 1.79 & $34.00-44.00$ & 88.33 & 9.81 & $76.00-142.00$ \\
\hline $\operatorname{ALP}(I U / L)$ & 48.16 & 3.90 & $32.00-61.00$ & 117.16 & 14.30 & $53.00-162.00$ \\
\hline $\mathrm{LDH}(\mathrm{IU} / \mathrm{L})$ & 128.75 & 11.91 & $86.40-157.20$ & 146.11 & 10.27 & $116.40-180.00$ \\
\hline Total protein $(\mathrm{g} / \mathrm{dl})$ & 4.33 & 0.30 & $3.00-5.00$ & 5.20 & 0.30 & $4.20-6.60$ \\
\hline Albumin $(\mathrm{g} / \mathrm{dl})$ & 1.17 & 0.14 & $0.68-1.80$ & 1.83 & 0.10 & $1.40-2.20$ \\
\hline Globulin ( $\mathrm{g} / \mathrm{dl})$ & 3.15 & 0.36 & $2.02-4.32$ & 3.36 & 0.26 & $2.80-4.60$ \\
\hline BUN (mg/dl) & 3.66 & 0.20 & $2.98-4.10$ & 7.40 & 0.52 & $5.60-9.00$ \\
\hline Creatinine $(\mathrm{mg} / \mathrm{dl})$ & 0.81 & 0.12 & $0.49-1.20$ & 0.50 & 0.04 & $0.34-0.68$ \\
\hline Cholesterol (mg/dl) & 198.33 & 16.19 & $156.00-250.00$ & 337.16 & 64.77 & $202.00-659.00$ \\
\hline Triglycerides (mg/dl) & 53.85 & 9.79 & $28.40-82.90$ & 242.8 & 25.05 & $125.00-320.00$ \\
\hline
\end{tabular}

ALT: Alanine aminotransferase, AST: Aspartate aminotransferase, ALP: Alkaline phosphatase, LDH: Lactate dehydrogenase, BUN: Blood urea nitrogen, G. gangeticus: Gavialis gangeticus

analysis is not feasible and also since blood collection is comparatively difficult in reptiles. In general reptiles have lower hematocrits (20-35\%). PCV $<18-$ $20 \%$ is indicative of anemia in a reptile patient [13]. However, in this investigation PCV values of gharials ranged between 17.30 and 23. No significant difference in PCV values was determined between juvenile and sub adult gharials. AST, ALP, BUN, triglycerides and albumin concentrations in sub adult gharials were significantly higher than juveniles. It is important to have known reference ranges of these enzymes and other serum constituents for understanding pathology and pathogenesis of diseases affecting gharial [13].

The hematological and serum biochemical values for gharials showed similarities and some notable differences when compared with values of other crocodilian species (Table-3). The comparisons between crocodilian families are observational, as statistical analyses were not possible. Some factors that might have affected parametric values obtained in earlier studies, such as complete methodology, environmental conditions including water chemistry, contaminant exposure, and ambient temperature, demographics and diet of the sample population may be unknown or may have differed between the studies These factors could have produced large differences, which are not reflections of true species differences. Therefore, it is, difficult to draw any firm conclusions regarding the biological significance of hematologic and biochemical differences between the species [10]. Additionally, the manual cell counting methods used in this investigation and other studies have a high rate of error [6]. However, the data obtained are still worth considering while interpreting blood values of a specific species, since they are the best that are currently available.

\section{Conclusion}

The study provided much-needed basic information on hematology and serum biochemistry in gharial. However, for a species specific reference range to be developed for gharial future studies with additional parameters and large sample sizes are required to evaluate the difference between genders and age classes. We also recommend analyzing other factors such as season, climatic conditions, source of gharials (captive or free-ranging) and perhaps a 
Table-3: Mean reference hematologic and biochemical values for some crocodilians compared with gharials (G. gangeticus). ${ }^{a}$

\begin{tabular}{|c|c|c|c|c|c|c|c|c|c|}
\hline \multirow[t]{2}{*}{ Parameter } & \multicolumn{2}{|c|}{ Mugger crocodileb } & \multicolumn{2}{|c|}{ Nile crocodilec } & \multirow{2}{*}{$\begin{array}{l}\text { Morelet's } \\
\text { crocodile }^{d} \\
(n=92)\end{array}$} & \multirow{2}{*}{$\begin{array}{c}\text { Salt } \\
\text { water } \\
\text { crocodile }\end{array}$} & \multirow{2}{*}{$\begin{array}{l}\text { American } \\
\text { alligator }^{f}\end{array}$} & \multicolumn{2}{|c|}{ Gharial } \\
\hline & $\begin{array}{l}\text { Juveniles } \\
(n=8)\end{array}$ & $\begin{array}{c}\text { Sub } \\
\text { adults } \\
(n=6)\end{array}$ & $\begin{array}{l}\text { J uveniles } \\
(n=11)\end{array}$ & $\begin{array}{c}\text { Sub } \\
\text { adults } \\
(n=5)\end{array}$ & & & & $\begin{array}{l}\text { Juveniles } \\
(n=6)\end{array}$ & $\begin{array}{c}\text { Sub } \\
\text { adults } \\
(n=6)\end{array}$ \\
\hline TEC (millions/ $\mu \mathrm{l})$ & 0.7 & 0.72 & 0.58 & 0.70 & 1.07 & $0.6-1.2$ & 0.67 & 0.91 & 1.17 \\
\hline $\mathrm{Hb}(\mathrm{g} / \mathrm{dl})$ & 9.41 & 7.68 & 7.16 & 8.62 & - & $4.7-12.2$ & $7.1-8.2$ & 7.01 & 7.86 \\
\hline PCV (\%) & 28.38 & 22.83 & 18.2 & 20.2 & 24.57 & $17-41$ & $20-30$ & 19.36 & 18.98 \\
\hline MCV (fl) & 407.14 & 315.17 & 315.3 & 311.0 & - & $240-311$ & 450 & 214.72 & 161.57 \\
\hline $\mathrm{MCH}(p g)$ & 133.38 & 106.07 & 124.2 & 134.2 & - & $72-92$ & 123 & 77.24 & 66.62 \\
\hline $\mathrm{MCHC}(\mathrm{g} / \mathrm{dl})$ & 33.2 & 33.65 & 39.4 & 42.8 & - & & - & 36.11 & 41.61 \\
\hline TLC (thousands/ $\mu \mathrm{l}$ ) & 10.04 & 8.11 & 13.53 & 11.45 & 9.09 & $6.4-25.7$ & - & 10.00 & 10.70 \\
\hline Heterophils (\%) & $\begin{array}{c}6.67 \\
\left(10^{3} / \mu \mathrm{l}\right)\end{array}$ & $\begin{array}{c}5.04 \\
\left(10^{3} / \mu \mathrm{l}\right)\end{array}$ & 19.4 & 16.8 & $\begin{array}{c}2.61 \\
\left(10^{3} / \mu \mathrm{l}\right)\end{array}$ & $\begin{array}{l}0.8-7.4 \\
\left(10^{3} / \mu \mathrm{l}\right)\end{array}$ & - & 26.00 & 28.50 \\
\hline Lymphocytes (\%) & $\begin{array}{c}2.72 \\
\left(10^{3} / \mu \mathrm{l}\right)\end{array}$ & $\begin{array}{c}2.65 \\
\left(10^{3} / \mu \mathrm{l}\right)\end{array}$ & 61.9 & 53.0 & $\begin{array}{c}4.13 \\
\left(10^{3} / \mu \mathrm{l}\right)\end{array}$ & $\begin{array}{l}4.5-21.6 \\
\left(10^{3} / \mu \mathrm{l}\right)\end{array}$ & - & 53.33 & 51.83 \\
\hline Eosinophils (\%) & $\begin{array}{c}0.56 \\
\left(10^{3} / \mu \mathrm{l}\right)\end{array}$ & $\begin{array}{c}0.29 \\
\left(10^{3} / \mu \mathrm{l}\right)\end{array}$ & 5.9 & 12.0 & $\begin{array}{c}0.26 \\
\left(10^{3} / \mu \mathrm{l}\right)\end{array}$ & $\begin{array}{l}0.0-0.7 \\
\left(10^{3} / \mu \mathrm{l}\right)\end{array}$ & - & 11.00 & 9.00 \\
\hline Monocytes (\%) & $\begin{array}{c}0.07 \\
\left(10^{3} / \mu \mathrm{l}\right)\end{array}$ & $\begin{array}{c}0.1 \\
\left(10^{3} / \mu \mathrm{l}\right)\end{array}$ & 0.4 & 0.6 & $\begin{array}{c}0.18 \\
\left(10^{3} / \mu \mathrm{l}\right)\end{array}$ & $\begin{array}{l}0.0-1.2 \\
\left(10^{3} / \mu \mathrm{l}\right)\end{array}$ & - & 3.83 & 3.33 \\
\hline $\begin{array}{l}\text { Monocytes (\%) (with } \\
\text { azurophillic granules) }\end{array}$ & - & - & 5.1 & 5.2 & $\begin{array}{c}0.20 \\
\left(10^{3} / \mu \mathrm{l}\right)\end{array}$ & - & - & 3.00 & 4.00 \\
\hline Basophils (\%) & $\begin{array}{c}0.01 \\
\left(10^{3} / \mu \mathrm{l}\right)\end{array}$ & $\begin{array}{c}0.02 \\
\left(10^{3} / \mu \mathrm{l}\right)\end{array}$ & 6.1 & 12.0 & $\begin{array}{c}1.69 \\
\left(10^{3} / \mu \mathrm{l}\right)\end{array}$ & $\begin{array}{l}0.0-0.4 \\
\left(10^{3} / \mu \mathrm{l}\right)\end{array}$ & - & 2.83 & 3.33 \\
\hline ALT (IU/L) & 53.38 & 63.5 & 45.54 & 34.40 & 20.20 & $11-51$ & - & 87.5 & 114.00 \\
\hline AST (IU/L) & 52.63 & 52.75 & 79.23 & 135.00 & - & $23-157$ & - & 39.66 & 88.33 \\
\hline ALP (IU/L) & 55.38 & 44.13 & 22.31 & 19.20 & - & $31-180$ & - & 48.16 & 117.16 \\
\hline $\mathrm{LDH}(\mathrm{IU} / \mathrm{L})$ & 139.38 & 125.13 & - & - & - & - & - & 128.75 & 146.11 \\
\hline Total protein $(\mathrm{g} / \mathrm{dl})$ & 3.15 & 3.11 & 41.41 & 52.42 & - & $4.1-7.0$ & 5.1 & 4.33 & 5.20 \\
\hline Albumin (g/dl) & 1.11 & 1.11 & 14.79 & 15.18 & - & $1.4-2.3$ & - & 1.17 & 1.83 \\
\hline Globulin (g/dl) & 2.04 & 2.00 & 26.62 & 37.24 & - & $2.7-5.0$ & - & 3.15 & 3.36 \\
\hline BUN (mg/dl) & 8.48 & 5.99 & - & - & - & - & - & 3.66 & 7.40 \\
\hline $\begin{array}{l}\text { Creatinine } \\
(\mathrm{mg} / \mathrm{dl})\end{array}$ & 0.41 & 0.43 & $\begin{array}{c}36.77 \\
(\mu \mathrm{mol} / \mathrm{I})\end{array}$ & $\begin{array}{c}34.40 \\
(\mu \mathrm{mol} / \mathrm{l})\end{array}$ & 2.7 & - & - & 0.81 & 0.50 \\
\hline $\begin{array}{l}\text { Cholesterol } \\
(\mathrm{mg} / \mathrm{dl})\end{array}$ & 295.88 & 244.13 & $\begin{array}{c}4.74 \\
(\mu \mathrm{mol} / \mathrm{I})\end{array}$ & $\begin{array}{c}4.47 \\
(\mu \mathrm{mol} / \mathrm{I})\end{array}$ & 250.14 & $42.5-278.4$ & - & 198.33 & 337.16 \\
\hline Triglycerides (mg/dl) & 323.75 & 32.13 & - & - & - & 8.86-127 & - & 53.85 & 242.8 \\
\hline
\end{tabular}

aThe blood values of juvenile and sub adult gharials were compared with juvenile and sub adult Mugger crocodiles and Nile crocodiles with different sample sizes. Blood values of gharial were also compared with reports in which class size was not specified or when sample population included animals of various sizes, bFrom Stacy and Whitaker [9], 'From Lovely et al. [10], 'From Padilla et al. [14], eAdapted from Millan et al. ( $n=29-120$, yearlings, range) [15], ${ }^{f}$ From Stein [3], TEC: Total erythrocyte count, Hb: Hemoglobin, PCV: Packed cell volume, MCV: Mean corpuscular volume, MCH: Mean corpuscular hemoglobin, MCHC: Mean corpuscular hemoglobin concentration, TLC: Total leukocyte count, ALT: Alanine aminotransferase, AST: Aspartate aminotransferase, ALP: Alkaline phosphatase, LDH: Lactate dehydrogenase, BUN: Blood urea nitrogen

quantitative habitat evaluation to establish reliable relationships between these parameters and the gharial's environment.

\section{Acknowledgments}

The authors are highly grateful to Dr. R.K. Sharma (Range Officer), National Chambal Sanctuary for the necessary facilities during the tenure of our study. Financial assistance from Madhya Pradesh State Forest Department for the study and in the form of Junior Research Fellowship to the first author is thankfully acknowledged. We are exceedingly thankful to Dr. Madhu Swamy, Professor and Head, Department of Pathology, College of Veterinary Science and Animal Husbandry, Jabalpur for technical and editorial assistance. We also thank Dr. M.A. Qadri, Professor, Department of Biochemistry, College of Veterinary Science and Animal Husbandry, Jabalpur, for help with the biochemical assays.

\section{Authors' Contributions}

SA and ABS collected blood samples from gharials for the study. SA carried out the current investigation under the guidance of ABS. SA drafted and revised the manuscript under the guidance of ABS. Both authors read and approved the final manuscript for publication.

\section{Competing I nterests}

The authors declare that they have no competing interests.

\section{References}

1. Convention on International Trade in Endangered Species. (2010) Convention on International Trade in Endangered Species of Wild Fauna and Flora. Available from: http// www.cites.org/eng/app/appendices.php. Last accessed on 25-08-2014.

2. Choudhury, B.C., Singh, L.A.K., Rao, R.J., Basu, D., Sharma, R.K., Hussain, S.A., Andrews, H.V., 
Whitaker, N., Whitaker, R., Lenin, J., Maskey, T., Cadi, A., Rashid, S.M.A., Choudhury, A.A., Dahal, B., Win, K.K.U., Thorbjarnarson, J., and Ross, J.P. (2007) Gavialis gangeticus. In: IUCN 2012. IUCN Red List of Threatened Species. Version 2012.2. Available from: http//www.iucnredlist.org/ details/8966/0. Last accessed on 25-08-2014.

3. Stein, G. (1996) Hematologic and blood chemistry values in reptiles. In: Mader D.R. editor. Reptile Medicine and Surgery. $2^{\text {nd }}$ ed. WB. Saunders Company Ltd., Philadelphia, Pennsylvania. p473-483.

4. Natt, M.P. and Herrick, C.A. (1952) A new blood diluent for counting the erythrocytes and leucocytes of chicken. Poult. Sci., 31: 735-738.

5. Feldman, B.F., Zinkl, J.G. and Jain, N.C. (2000) Schalm’s Veterinary Hematology. $5^{\text {th }}$ ed. Lea and Fibiger, Philadelphia, USA.

6. Jain, N.C. (1986) Hematologic techniques. In: Jain, N.C. editor. Schalm's Veterinary Hematology. Lea and Febiger, Philadelphia, Pennsylvania, USA. p36-66.

7. Arykan, H.B., Mehmet, G., Yildiz, Z., Ilgaz, C. and Kumluta, Y. (2009) Morphology of peripheral blood cells from some lacertid lizards from Turkey. Russ. J. Herpetol., 16(2): 101-106.

8. Snedecor, C.W. and Cochran, W.G. (1994) Statistical Methods. $6^{\text {th }}$ ed. Oxford and IBH Publishing Co., Bombay. p593.

9. Duguy R. (1970) Numbers of blood cells and their variation.
In: Gans, C. and Parsons, T.S. editors. Biology of Reptilia. Acad Press, New York. p93-109.

10. Stacy, B.A. and Whitaker, N. (2000) Hematology and blood biochemistry of captive mugger crocodiles (Crocodylus palustris). American Association of Zoo Veterinarians. J. Zoo. Wildl. Med., 31(3): 339-347.

11. Lovely, C.J., Pittman, J.M. and Leslie, A.J. (2007) Normal hematology and blood biochemistry of wild Nile crocodiles (Crocodylus niloticus) in the Okavango Delta, Botswana. J. S. Afr. Vet. Assoc., 78(3): 137-144.

12. Saint Girons, M.C. and Saint Girons, H. (1969) Contribution à la morphologie comparée des érythrocytes chez les reptiles. Br. J. Herpetol., 4: 67-82.

13. Mitchell, M.A. (2001) Reptile Clinical Pathology. In: Proceedings of the North American Veterinary Conference. Orlando Florida, USA. p808-809.

14. Padilla, S.E., Weber, M. and Jacobson, E.R. (2011) Hematologic and plasma biochemical reference intervals for Morelet's crocodiles (Crocodylus moreletii) in the northern wetlands of Campeche, Mexico. J. Wildl. Dis., 47(3): 511-522.

15. Millan, J.M., Janmaat, A., Richardson, K.C., Chambers, L.K. and Fomiatti, K.R. (1997) Reference ranges for biochemical and hematological values in farmed saltwater crocodile (Crocodylus porosus) yearlings. Aust. Vet. J., 75: 814-817. 